\title{
Evaluation of the antifungal activity and mode of action of Lafoensia pacari A. St.-Hil., Lythraceae, stem-bark extracts, fractions and ellagic acid
}

\author{
Iberê F. Silva Junior, ${ }^{1,5}$ Marcela Raimondi, ${ }^{2}$ Susana Zacchino, ${ }^{2}$ Valdir Cechinel Filho, ${ }^{3}$ \\ Vânia F. Noldin, ${ }^{3}$ Vietla S. Rao, ${ }^{4}$ Joaquim C. S. Lima, ${ }^{1}$ Domingos T. O. Martins ${ }^{*}, 1$
}

\author{
${ }^{1}$ Departamento de Ciências Básicas em Saúde, Faculdade de Ciências Médicas, Universidade Federal de Mato \\ Grosso, Av. Fernando Corrêa da Costa s/n, Cidade Universitária, 78060-900 Cuiabá-MT, Brasil, \\ ${ }^{2}$ Farmacognosia, Facultad de Ciencias Bioquímicas y Farmacéuticas, Universidad Nacional del Rosario, \\ Suipacha, 531 Rosario, Argentina, \\ ${ }^{3}$ Núcleo de Investigações Químico-Farmacêuticas, Universidade do Vale do Itajaí, 88302-202 Itajaí-SC, Brasil, \\ ${ }^{4}$ Departamento de Fisiologia e Farmacologia, Faculdade de Medicina, Universidade Federal do Ceará, \\ Rua Cel. Nunes de Melo, 1127, 60430-275 Fortaleza-CE, Brasil, \\ ${ }^{5}$ Faculdade de Farmácia, Universidade de Cuiabá, 78015-480 Cuiabá-MT, Brasil.
}

\begin{abstract}
RESUMO: “Avaliação da atividade antifúngica e modo de ação dos extratos da entrecasca, frações e ácido elágico de Lafoensia pacari A. St.-Hil., Lythraceae,”. Os extratos, frações e ácido elágico, isolados da entrecasca de Lafoensia pacari A. St.-Hil., Lythraceae, foram testados in vitro para atividade antifúngica, frente a um painel de leveduras, hialo-hifomicetos e dermatófitos, utilizando o método de microdiluição. O extrato EtOH, frações e ácido elágico exibiram atividade contra Candida spp. e Saccharomyces cerevisiae com valores de CIM entre 250-1000 $\mu \mathrm{g} / \mathrm{mL}$, porém não mostraram ação contra fungos filamentosos e dermatófitos (CIM>1000 $\mu \mathrm{g} / \mathrm{mL})$. Os extratos ativos foram avaliados nos ensaios de inibição do crescimento das hifas de Neurospora crassa, no teste do sorbitol, e pelo estudo do efeito do ergosterol na CIM do ácido elágico. Os extratos ativos, frações e ácido elágico mostraram zonas manchadas ao redor dos discos de papel e induziram malformações nas hifas. Além disso, a CIM do ácido elágico contra Saccharomyces cerevisiae passou de 62 para $250 \mu \mathrm{g} / \mathrm{mL}$ na presença do sorbitol $0,8 \mathrm{M}$, sugerindo que o ácido elágico provavelmente poderia exercer ação na parede celular fúngica. Esses resultados indicam que o ácido elágico pode ser o principal composto antifúngico de Lafoensia pacari, sugerindo que o modo de ação antifúngico desses extratos e ácido elágico poderia estar associado à inibição da parede celular fúngica.
\end{abstract}

Unitermos: Lafoensia pacari, mangava-brava, atividade antifúngica, extratos e frações, inibição da parede celular, ácido elágico.

\begin{abstract}
Stem-bark extracts, fractions and the isolated constituent, ellagic acid of Lafoensia pacari St. Hil. (Lythraceae) were in vitro assayed for antifungal activity against a panel of yeasts, hialohyphomycetes as well as dermatophytes with the microbroth dilution method. The EtOH extract and its fractions and ellagic acid exhibited activity against Candida spp and Saccharomyces cerevisiae with MIC values between $250-1000 \mu \mathrm{g} / \mathrm{mL}$, but they showed no action against filamentous fungi and dermatophytes (MIC $>1000 \mu \mathrm{g} / \mathrm{mL}$ ). Active extracts were evaluated in Neurospora crassa hyphal growth inhibition and sorbitol assays and then the effect of ergosterol on the MIC of ellagic acid was studied. The active extracts and its fractions and ellagic acid showed a blotchy zone around the paper disk and induced malformations of the hypha. Besides, MIC of the ellagic acid against the Saccharomyces cerevisiae was raised from 62 to $250 \mu \mathrm{g} / \mathrm{mL}$ in the presence of sorbitol $0.8 \mathrm{M}$, suggesting that the ellagic acid would probably exert its action on fungal cell wall. These results indicate that ellagic acid might be the main active antifungal compound of Lafoensia pacari and further suggest that the mode of antifungal action of these extracts and ellagic acid could be associated with the inhibition of fungal cell wall.
\end{abstract}

Keywords: Lafoensia pacari, mangava-brava, antifungal activity, extracts and fractions, inhibition of cell wall, ellagic acid. 


\section{INTRODUCTION}

In the last twenty years, there has been a notable increase in fungal infections all throughout the world, more so among the growing number of immunocompromised patients (Quindos, 2002). Due to the ineffectiveness or toxicity of antifungal drugs currently available, treatment of human mycoses is very difficult (Barberán et al., 2008). The mode of action of most known antifungal drugs in use nowadays, is the inhibition of some of the steps of ergosterol biosynthesis, which is common to human cholesterol and sexual hormones biosynthesis too. As a consequence, many adverse effects have been reported for them (Zacchino et al., 2003; Kartsonis et al., 2003). Since fungal but not mammalian cells are encased in a wall, which serves as a protective barrier and is required for growth and viability of fungi, its inhibition represents an ideal mode of action of antifungal agents (Onishi et al., 2000).

In the course of our screening program to look for new antifungal Brazilian plant extracts from the rich biodiversity of Cerrado region (Figure 1), whose mode of action was the inhibition of fungal cell wall, we tested Lafoensia pacari A. St. Hil., Lythraceae, a tree commonly known as "mangava-brava" or "pacari". The macerate prepared from the stem bark is a popular remedy for the treatment of wound healing, fever, gastric ulcer, gastritis, utero inflammation and upheavals of biliary vesicle (Guarim Neto \& Moraes, 2003). Previous works have shown that Lafoensia pacari stem bark ethanol and methanol extracts possess anti-ulcer (Tamashiro-Filho,
1999), anti-inflammatory (Albuquerque, 1996a, Rogerio et al., 2008a), immunostimulating (Albuquerque, 1996b), free radicals scavenging (Solon et al., 2000), antiviral (Müller et al., 2007), anti-eosinophilic (Rogerio et al., 2008b), analgesic and anti-oedematous (Rogerio et al., 2006) and inhibition of interleukin (IL)-5 production (Rogerio et al., 2003) activities. According to Solon (1999), this plant is rich in ellagic acid, which presents gastric anti-secretory (Murakami et al., 1991) and antibacterial effects (Chung, 1998; Lima et al., 2006) and a recent clinical study carried out with Lafoensia pacari extract revealed positive effects on the symptomatology of Helicobacter pylori infected patients (Mota Menezes et al., 2006), but to the best of our knowledge, there was no published report on the plant's antifungal properties.

We present here the antifungal properties of the different extracts, fractions and ellagic acid of $L$. pacari. At first, we tested them using the microbroth dilution method against a panel of standardized yeasts, filamentous fungi as well as dermatophytes. Then, to gain insight into the mode of action, the whole-cell Neurospora crassa hyphal growth inhibition assay, was performed on them. This method is useful to detect agents whose mode of action is associated with inhibition of the fungal cell wall (Fukuda et al., 1991). In addition, since fungal cells shows changes in morphological features after treatment with drugs that interfere with the biosynthesis of fungal wall (Gunji et al., 1983; Fukushima et al., 1993), the microscopical appearance of fungal hypha treated with extracts of $L$. pacari is also described.

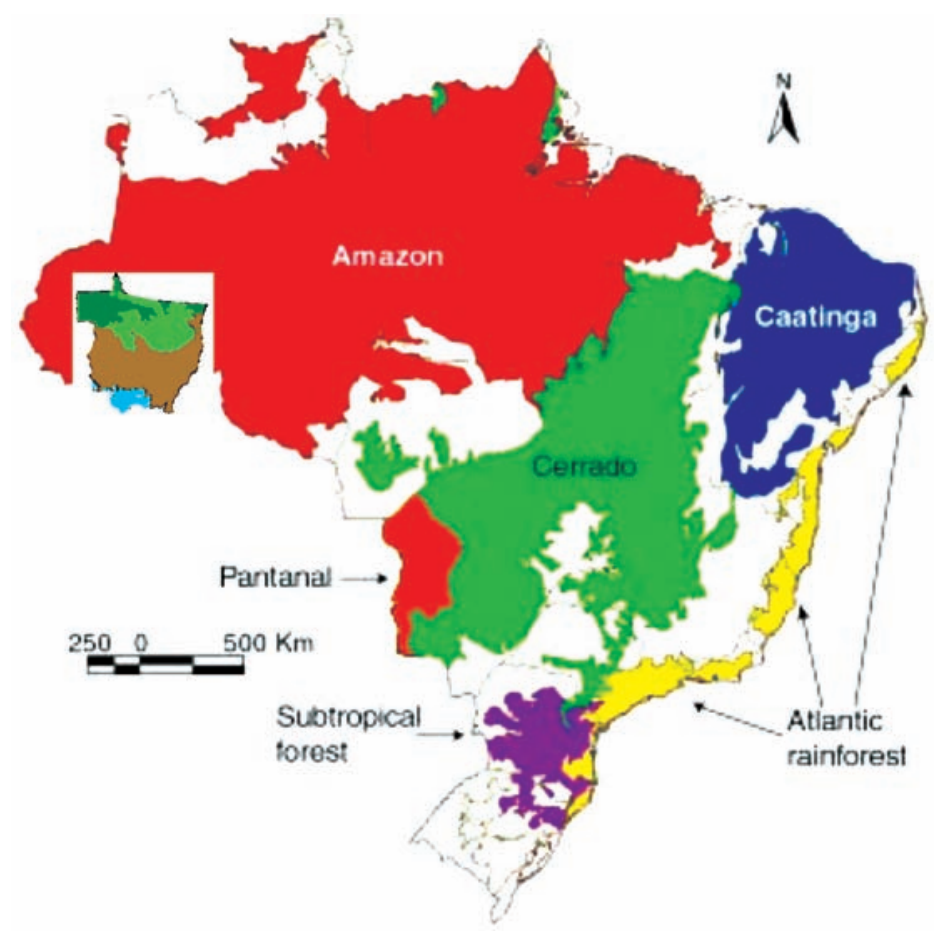

Figure 1. Cerrado region within the State of Mato Grosso where Lafoensia pacari A. St. Hil. were collected. Source: Embrapa, Cenargen, 1999. 


\section{MATERIAL AND METHODS}

\section{Plant material and phytochemical analysis}

Lafoensia pacari A. St.-Hil., Lythraceae, stem bark was collected $(675 \mathrm{~g})$ in Várzea Grande Municipality of Mato Grosso State, Brazil, and its botanical identity was confirmed by Harri Lorenzi of the Plantarum Institute, in Nova Odessa-SP, Brazil. A voucher specimen ( $\mathrm{N}^{\circ}$. 35577) was deposited at the Central Herbarium of Federal University of Mato Grosso. The collection was authorized by the Brazilian Institute of Environment and Renewable Natural Resources.

The stem bark was dried at $40{ }^{\circ} \mathrm{C}$ for three days to constant weight $(520 \mathrm{~g})$ and later triturated. The dried powdered material $(200 \mathrm{~g})$ was macerated successively with n-hexane, dichloromethane, ethyl acetate and ethanol $75 \%(3: 1 \mathrm{w} / \mathrm{v})$ at room temperature for seven days to yields residues of $115.80 ; 377.70 ; 758.00 \mathrm{mg}$ and $6.52 \mathrm{~g}$, respectively. Each macerate was separated by filtration and concentrated under reduced pressure. Active ethyl acetate extract was fractionated with methanol $(6.4 \mathrm{~g})$ and acetone $(436 \mathrm{mg})$. The fractions of methanol and acetone had been obtained by chromatography in column (CC), using silica Gel 60 (70-230 mesh) (Cechinel Filho \& Yunes, 1998), while the phytochemical analysis was performed according to literature procedure, such as colorations and precipitations tests (Matos, 1988).

\section{Isolation and identification of ellagic acid}

Ellagic acid was detected by thin layer chromatography (TLC) in both fractions (acetone and methanol), but in more concentration on methanol fraction. A part of a last $(500 \mathrm{mg})$ was chromatographed several times over Sephadex LH-20, eluted with $\mathrm{MeOH}: \mathrm{H}_{2} \mathrm{O}$ gradient, giving $25 \mathrm{mg}$ of pure ellagic acid. It was identified by usual spectroscopic methods (IR, RMN ${ }^{1} \mathrm{H}$ and ${ }^{13} \mathrm{C}$ ) and direct comparison with an authentic sample.

\section{Microorganisms}

Antifungal activity was studied using microorganisms from the American Type Culture Collection (ATCC, Rockville, MD, USA) or clinical isolates provided by the Centro de Referencia en Micología (C, Ceremic), Facultad de Ciencias Bioquímicas y Farmacéuticas, Suipacha 531, (2000) Rosario, Argentina and the Institute Adolfo Lutz, São Paulo, Brazil (IAL): Candida albicans ATCC 10231, Candida krusei ATCC 6258, Candida tropicalis ATCC 750, Candida parapsilosis ATCC 22019, Candida glabrata ATCC 90030, Saccharomyces cerevisiae ATCC 9763, Cryptococcus neoformans ATCC 32264, Neurospora crassa ATCC 9279, Aspergillus niger ATCC 16404, Candida lusitaneae C131, Candida kefyr C123 and Candida colliculosa C122, Aspergillus flavus IAL
552, Aspergillus fumigatus IAL 640, Microsporum canis IAL 578, Microsporum gypseum IAL 579, Trichophyton rubrum IAL 612, Trichophyton mentagrophytes IAL 581, Trichophyton tonsurans IAL 592 and Epidermophyton floccosum IAL 577. The strains were maintained on slopes of Sabouraud-dextrose agar (Oxoid) and subcultured every fifteen days to prevent pleomorphic transformations.

\section{Antifungal assays}

\section{Agar diffusion assay}

The agar diffusion assay described for Clinical and Laboratory Standards Institute (CLSI), formerly National Committee for Clinical and Laboratory Standards (NCCLS) (CLSI M44-A, 2002) was adopted. Petri dishes has been prepared with Müller-Hinton agar (Oxoid) supplemented with $2 \%$ of glucose (Oxoid) and inoculated in its surface $10^{4}-10^{6}$ yeast-cells or spores $/ \mathrm{mL}$. The compound tests had been dissolved in DMSO 1\% to prepare stock solution. Records of barren paper had been impregnated with the test solution to reach final concentration up to $100 \mu \mathrm{g}$ of extract/disk, being $30 \mu \mathrm{g}$ for ketoconazol and $100 \mu \mathrm{g}$ for amphotericin B, used as standards. Dimethyl sulfoxide (DMSO) $15 \mu \mathrm{L}$ served as negative control. The assays had been carried through in duplicate and the results expressed in $\mathrm{mm}$, using arithmetic mean of the diameter of growth inhibition zones formed around the disks. This assay was carried out in duplicate.

\section{Minimal inhibitory concentration (MIC)}

MIC values were determined using microplates of 96 wells following the guidelines of CLSI, M27-A2 for yeasts and M38-A for filamentous fungi. All guidelines were followed with the exception of the incubation temperature, which was recommended as $35^{\circ} \mathrm{C}$ by CLSI for both type of fungi but we used $30^{\circ} \mathrm{C}$. This change was made in order to allow the growth of all type of fungi, since not all dermatophytes grow at $35^{\circ} \mathrm{C}$. Stock solutions of extracts, fractions and ellagic acid diluted in DMSO were added to each medium to give serial two-fold dilutions, resulting in concentrations ranging from 1000 to $8 \mu \mathrm{g} /$ $\mathrm{mL}$ for extract, fractions and ellagic acid. Inocula of 100 $\mu \mathrm{L}\left(10^{3}-10^{4} \mathrm{CFU} / \mathrm{mL}\right)$ were added to RPMI-1640 broth medium (Sigma). Amphotericin B (Sigma) and terbinafine were used as positive controls. Plates were incubated for 24,48 or $72 \mathrm{~h}$ at $30^{\circ} \mathrm{C}$ (according to the control fungus growth) up to fifteen days for dermatophyte strains. MIC was defined as the lowest concentration of extracts and fractions capable to the total inhibition of the growth of fungi. All antifungal assays were tested in duplicate.

\section{Neurospora crassa assay}

Thirty $\mathrm{mL}$ of a medium containing $0.5 \%$ proteose 
peptone (Difco), $0.5 \%$ yeast extract (Merck), $4 \%$ sucrose (Merck) and 1.5\% agar (Merck) was autoclaved (121 ${ }^{\circ} \mathrm{C}, 15 \mathrm{~min}$ ), inoculated with $25 \mu \mathrm{L}$ of spore inoculum of Neurospora crassa (ATCC 9279) 1x $10^{7}$ free of hypha at $40{ }^{\circ} \mathrm{C}$ and then layered on Petri dish (diameter, $9 \mathrm{~cm}$ ). After the medium has solidified, paper disks containing $100 \mu \mathrm{g}$ of extract/disk were applied into media. Ketoconazol (30 $\mu \mathrm{g}$ CECON, São Paulo, Brazil) was used as positive control to produce a clear zone. Zones of inhibition were examined macroscopically for hazy or mottled appearance following incubation of the plates at room temperature for $24 \mathrm{~h}$ with light. In those cases where hazy zones were observed, the microscopic appearance of hypha were analysed.

\section{Sorbitol assay}

The MIC of ellagic acid was determined with Saccharomyces cerevisiae ATCC 9763 using the broth microdilution method (CLSI M27-A2). Sorbitol was added to the culture medium to give a final concentration of 0.8 $\mathrm{M}$. Following incubation at $25^{\circ} \mathrm{C}$, the plates were read at $48 \mathrm{~h}$ and after seven days (Frost et al., 1995). This assay was carried out in duplicate.

\section{Effect of ergosterol in MIC of ellagic acid}

The MIC of the ellagic acid against Saccharomyces cerevisiae ATCC 9763 was determined by microdilution method (CLSI M27-A2), without or with the addition of ergosterol (Sigma) at concentrations of 50, 100 and 200 $\mu \mathrm{g} / \mathrm{mL}$ This assay was carried out in duplicate.

\section{RESULTS AND DISCUSSION}

The antifungal property of extracts, fractions and ellagic acid was evaluated with the broth dilution method following the guidelines of the Clinical and Laboratory Standards Institute for yeasts (CLSI M27-A2) and filamentous fungi (CLSI M38-A) against a panel of yeast, hyalohyphomycetes as well as dermatophytes. MIC values $\leq 1000 \mu \mathrm{g} / \mathrm{mL}$ were considered active (Table 1).

Disks containing $100 \mu \mathrm{g}$ of compound tests had been used for the agar diffusion assay. Zones of inhibition $\geq$ $10 \mathrm{~mm}$ were considered active. The results of disk-diffusion had evidenced antifungal activity only for the yeast-cells, thus showing selectivity for yeasts. The $n$-hexane and

Table 1. Antifungal activity of extracts, fractions and ellagic acid from Lafoensia pacari against yeasts, filamentous fungi and dermatophytes in broth dilution assays.

\begin{tabular}{|c|c|c|c|c|c|c|c|c|}
\hline \multirow[b]{2}{*}{ Strains } & \multirow[b]{2}{*}{ Amphotericin B } & \multirow[b]{2}{*}{ Terbinafine } & \multicolumn{4}{|c|}{ Ellagic acid and extracts } & \multicolumn{2}{|c|}{ Fractions from $\mathrm{TOH}$} \\
\hline & & & $\begin{array}{c}\text { Ellagic } \\
\text { acid }\end{array}$ & Hexane & DCM & $\mathrm{EtOH}$ & $\mathrm{MeOH}$ & Acetone \\
\hline C. albicans & $0.78^{\mathrm{a}}$ & - & 500 & $>1000$ & $>1000$ & $>1000$ & 1000 & 1000 \\
\hline C. krusei & 1.0 & - & 125 & $>1000$ & $>1000$ & 1000 & 250 & 500 \\
\hline C. parapsilosis & 0.25 & - & 125 & $>1000$ & $>1000$ & 500 & 500 & 250 \\
\hline C. tropicalis & 1.56 & - & 125 & $>1000$ & $>1000$ & $>1000$ & 500 & 1000 \\
\hline C. glabrata & 0.5 & - & $>1000$ & $>1000$ & $>1000$ & $>1000$ & $>1000$ & $>1000$ \\
\hline C. lusitaneae & 1.0 & - & $>1000$ & $>1000$ & $>1000$ & $>1000$ & $>1000$ & $>1000$ \\
\hline C. kerfyr & 0.5 & - & $>1000$ & $>1000$ & $>1000$ & $>1000$ & $>1000$ & $>1000$ \\
\hline C. colliculosa & 1.0 & - & $>1000$ & $>1000$ & $>1000$ & $>1000$ & $>1000$ & $>1000$ \\
\hline S. cerevisiae & 0.78 & - & 62 & $>1000$ & $>1000$ & 500 & 250 & 250 \\
\hline C. neoformans & 0.78 & - & $>1000$ & $>1000$ & $>1000$ & 1000 & $>1000$ & $>1000$ \\
\hline A. niger & 0.78 & - & $>1000$ & $>1000$ & $>1000$ & $>1000$ & $>1000$ & $>1000$ \\
\hline A. flavus & 0.78 & - & $>1000$ & $>1000$ & $>1000$ & $>1000$ & $>1000$ & $>1000$ \\
\hline A. fumigatus & 3.12 & - & $>1000$ & $>1000$ & $>1000$ & $>1000$ & $>1000$ & $>1000$ \\
\hline M. canis & - & 0.01 & $>1000$ & $>1000$ & $>1000$ & $>1000$ & $>1000$ & $>1000$ \\
\hline M. gypseum & - & 0.04 & $>1000$ & $>1000$ & $>1000$ & $>1000$ & $>1000$ & $>1000$ \\
\hline T. rubrum & - & 0.01 & $>1000$ & $>1000$ & $>1000$ & $>1000$ & $>1000$ & $>1000$ \\
\hline T. mentagrophytes & - & 0.04 & $>1000$ & $>1000$ & $>1000$ & $>1000$ & $>1000$ & $>1000$ \\
\hline T. tonsurans & - & 0.02 & $>1000$ & $>1000$ & $>1000$ & $>1000$ & $>1000$ & $>1000$ \\
\hline E. floccosum & _- & 0.004 & $>1000$ & $>1000$ & $>1000$ & $>1000$ & $>1000$ & $>1000$ \\
\hline
\end{tabular}

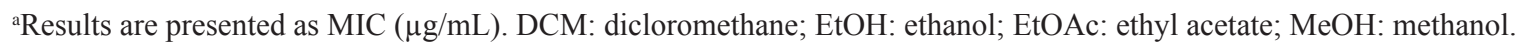


dichloromethane extracts were not active against the other members of the fungal panel (Table 2). Results of broth dilution assays (Table 1) showed that only the EtOH extract and ellagic acid possesses antifungal activity. They inhibit the growth of yeasts Candida krusei, Candida parapsilosis and Saccharomyces cerevisiae with MIC values between $500-1000 \mu \mathrm{g} / \mathrm{mL}$, but showed no efficacy against filamentous fungi and dermatophytes (MIC $>1000 \mu \mathrm{g} / \mathrm{mL}$ ). The active extract was fractionated between acetone and $\mathrm{MeOH}$ and the fractions and ellagic acid were tested in the panel of fungi. Both fractions and ellagic acid showed better activity than EtOH extract against Candida krusei, Candida parapsilosis and Saccharomyces cerevisiae (MIC $=250-500 \mu \mathrm{g} / \mathrm{mL}$ ) and in addition they were also found to be active against Candida albicans (MIC $=1000 \mu \mathrm{g} / \mathrm{mL}$ ) and Candida tropicalis ( $\mathrm{MIC}=500-1000 \mu \mathrm{g} / \mathrm{mL}$ ).

To gain insight into the mode of action of active extracts and fractions, they were evaluated for their capacity to interfere with fungal cell wall. Amongst methods that deal with this mode of action, we have chosen the Neurospora crassa assay, an agar diffusion method which allows us to detect macroscopically drugs that interfere with the biosynthesis or assembly of the fungal cell wall. Neurospora crassa usually grows as long hypha in a diffuse or branched way. When it grows in the presence of certain inhibitors of the cell wall, the hyphal growth is inhibited, and fungi grow as protoplasts. Macroscopically they can be seen as a blotchy or hazy appearance around the paper disk. The microscopic observation of this hazy zone showed morphological changes (Fukushima et al., 1993) such as shortened, anomalously ramified and zigzag hypha, suggesting that the possible mode of antifungal action of these extracts, fractions and ellagic acid could be associated with the inhibition of fungal cell wall. Results obtained in the Neurospora crassa assay for active extracts, fractions and ellagic acid of Lafoensia pacari are shown on Table 3 and Figure 2.

The sorbitol assay consists of determining MIC in the presence and absence of sorbitol $0.8 \mathrm{M}$, which has an osmoprotector function and is essential for fungal growth. Fungal cells that lack cell wall or with impaired cell wall cannot grow in the absence of sorbitol. However, its growth will still be possible if sorbitol is supplemented. The inhibitors of the fungal cell wall could be identified when the MIC values obtained with sorbitol are higher than the ones in its absence after seven days of incubation (Frost et al., 1995). In the present assays, MIC of the ellagic acid against Saccharomyces cerevisiae was raised from 62 to $250 \mu \mathrm{g} / \mathrm{mL}$ in the presence of sorbitol $0.8 \mathrm{M}$, suggesting that the ellagic acid would act modifying the fungal cell wall, while the MIC of the amphotericin B was not modified, as expected.

To verify whether or not ellagic acid acts as an antifungal agent by acting on ergosterol, one observed the values of the MIC of same in the presence of increasing concentrations of ergosterol. If this mechanism operates, the MIC of the test compounds will be much higher in the presence of ergosterol than that in its absence (Lee et al., 1999). The results had shown that MIC of amphotericin B against Saccharomyces cerevisiae increased with the change to addition of ergosterol, while that of the ellagic acid remained unaltered, suggesting a different mode of action.

Extracts, fractions and ellagic acid of Lafoensia pacari evidenced good antifungal activity against Saccharomyces cerevisiae and Candida spp. and within this genus, mainly against Candida no-albicans such as Candida krusei and Candida parapsilosis. As it is well-known, Candida spp., are among the leading cause of nosocomial blood stream infections worldwide. In the past, Candida albicans was the usual species associated with invasive mycoses. At present, there is an epidemiological shift towards Candida krusei and other Candida no-albicans infections, which have increased in many medical centers (Fromtling, 1999). In aggravation, they are resistant to most available antifungal drugs (Grau Cerrato et al., 1996).

Phytochemical investigation with the methanol stem bark extract of Lafoensia pacari revealed the presence of tannins, steroids, triterpenes and saponins, which

Table 2. Antifungal activity of extracts, fractions and ellagic acid of Lafoensia pacari against yeasts in agar diffusion assay.

\begin{tabular}{|c|c|c|c|c|c|c|c|}
\hline \multirow{3}{*}{$\begin{array}{c}\text { Plant deriveds and } \\
\text { standard }\end{array}$} & \multirow{3}{*}{$\mu \mathrm{g} /$ disk } & \multicolumn{6}{|c|}{ Inhibition halos (mm) } \\
\hline & & \multicolumn{6}{|c|}{ Strain } \\
\hline & & $\mathrm{Ca}$ & $\mathrm{Ck}$ & Cp & $\mathrm{Ct}$ & Sc & $\mathrm{Cn}$ \\
\hline Ethanol extract & 100 & --- & $12^{\mathrm{a}}$ & 10 & --- & 09 & 10 \\
\hline Ethyl acetate extract & 100 & --- & 10 & 10 & --- & 08 & 12 \\
\hline Methanol fraction & 100 & 10 & 11 & 11 & 11 & 15 & --- \\
\hline Acetone fraction & 100 & 10 & 13 & 16 & 12 & 15 & --- \\
\hline Ellagic acid & 100 & 13 & 15 & 20 & 13 & 17 & 15 \\
\hline Amphotericin B & 100 & 25 & 11 & 30 & 20 & 20 & 20 \\
\hline
\end{tabular}

a Inhibition halos (mm); C. albicans; Ck: C. krusei; Cp: C. parapsilosis; Ct: C. tropicalis; Sc: S. cerevisiae; Cn: C. neoformans; ---: not observed. 
contains several secondary metabolites well-known for their antimicrobial activity (Solon et al., 2000). Solon et al. (2000), using HPLC analysis and analytical TLC showed that ellagic acid is the main constituent of Lafoensia pacari. Similar results were evidenced in our study, which showed that ellagic acid is responsible, at least in part, for the antifungal activity of Lafoensia pacari.

The antifungal activity of extracts, fractions and an active compound (ellagic acid) from Lafoensia pacari towards Candida spp., and the probable selective target of action (fungal cell wall) evidenced from the results obtained in Neurospora crassa assay make this plant an attractive Brazilian species for more advanced antifungal targeted tests.

Therefore, the correlation of data obtained with traditional indication of Lafoensia pacari stem bark preparations can contribute for the treatment of the different diseases caused by fungi.

Table 3. Neurospora crassa assay of extracts, fractions and ellagic acid from Lafoensia pacari stem bark.

\begin{tabular}{cc}
\hline Plant deriveds and standard & Neurospora crassa assay $^{\mathrm{a}}$ \\
\hline Ethyl acetate extract & Hazy \\
Ethanol extract & Hazy \\
Methanol fraction & Hazy \\
Acetone fraction & Hazy \\
Ellagic acid & Hazy \\
Ketoconazol & Clear \\
\hline
\end{tabular}

${ }^{a}$ Aspect of the inhibition zone

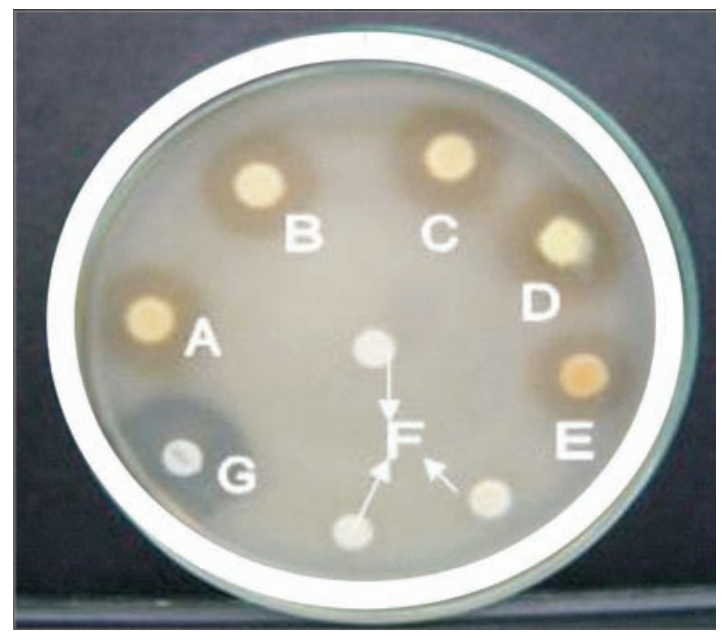

Figure 2. Mottled halos showed by extracts and fractions and ellagic acid from Lafoensia pacari and clear halos obtained with ketoconazol in the Neurospora crassa assay. (A and B) EtOH extract, (C) acetone fraction, (D) $\mathrm{MeOH}$ fraction, (E) Ellagic acid, (F) DMSO and (G) ketoconazol.

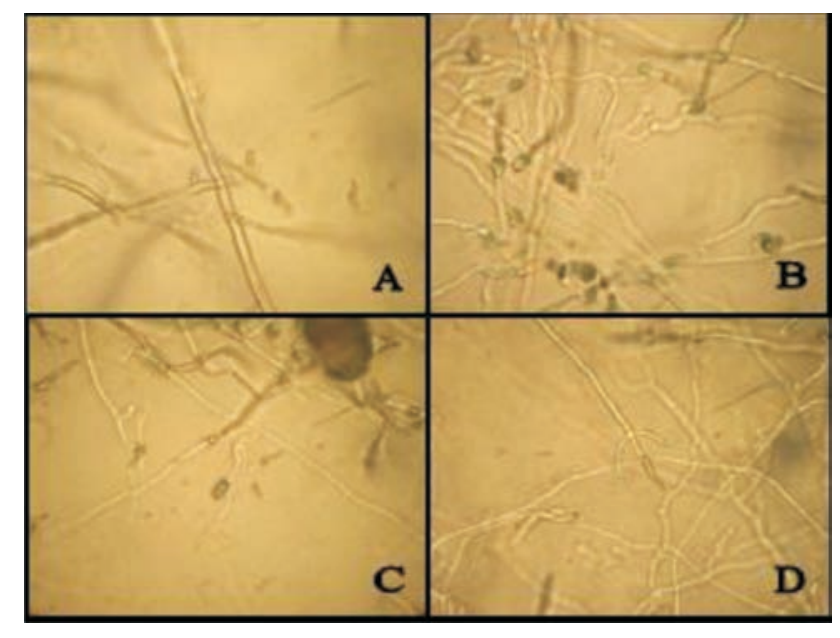

Figure 3. Effect of ellagic acid of Lafoensia pacari on the morphology of Neurospora crassa. (A) normal growth, (B) hypha in zig-zag, (C) short hypha, (D) anomalous ramified hypha.

\section{ACKNOWLEDGEMENTS}

The authors are grateful to CNPq, CAPES and CYTED (RIBIOFAR RT 0284 network) for financial support. SZ acknowledges to ANPCyT PICT 995.

\section{REFERENCES}

Albuquerque DA 1996a. Efeito do extrato etanólico de Lafoensia pacari sobre a peritonite aguda em camundongos. In: Programa e Anais $3^{a}$ Reunião especial da SBPC "Ecossistemas Costeiros-do conhecimento a gestão", Florianópolis, SC, UFSC.

Albuquerque DA 1996b. Efeito do extrato etanólico de Lafoensia pacari sobre a produção de anticorpos in vitro. In: Programa e Anais $3^{a}$ Reunião especial da SBPC "Ecossistemas Costeiros-do conhecimento a gestão", Florianópolis, SC, UFSC.

Barberán J, Mensa J, Fariñas C, Llinares P, Serrano R, Menéndez R, Agustí C, Gobernado M, Azanza J, García Rodríguez $\mathrm{J}$ 2008. Recommendations of antifungal treatment in patients with low grade inmunosuppression. Rev Esp Quimioter 21: 127-142.

Cechinel Filho V, Yunes RA 1998. Strategies for obtaining pharmacologically active compounds from medicinal plants. Concepts about structural modification for improve the activity. Quim Nova 21: 99-105.

Chung JG 1998. Inhibitory actions of ellagic acid on growth and arylamine $N$-acetyltransferase activity in strains of Helicobacter pylori from peptic ulcer patients. Microbios 93: 115-127.

CLSI (Clinical and Laboratory Standards Institute) formely NCCLS (National Committee for Clinical Laboratory Standards). 2002. Method M27-A2, 2nd ed. Wayne Ed.; 22: 1-29. NCCLS, and method M38-A, $2^{\text {nd }}$ ed, Wayne Ed.; 22: 1-27.

CLSI (Clinical Laboratory Standards Institute) formely NCCLS (National Committee for Clinical Laboratory Standards) 2002. Method for antifungal disk diffusion susceptibility 
testing in yeasts. Approved guideline, vol. M44-A. CLSI, Wayne, Pa.

Fromtling RA 1999. Progress in antifungal chemotherapy. Drug News Perspect 12: 557-569.

Frost DJ, Brandt KD, Cugier D, Goldman RJ 1995. A whole-cell Candida albicans assay for the detection of inhibitors towards fungal cell wall synthesis and assembly. $J$ Antibiot 48: 306-310.

Fukuda D, Nakatsukasa W, Yao R, Hunt A, Gordee R, Zeckner D, Mynderse J 1991. A45507, a complex of fungal cell wall inhibitors produced by a mold. $31^{\text {st }}$ ICAAC Meeting (Chicago, Il, USA) poster \# 211.

Fukushima Y, Sakagami Y, Marumo S 1993. $\beta$-Glucan biosynthesis inhibitors isolated from fungi as hyphal malformation inducer. Bioorg Med Chem Lett 3: 1219-1222.

Grau Cerrato S, Torres Rodríguez J, Monterde Junyent J 1996. Situación actual de las infecciones por hongos: ¿son las anfotericinas lipídicas la panacea? Farm Hosp 20: 390392.

Guarim Neto G, Morais RG 2003. Medicinal plants resources in the Cerrado of Mato Grosso State, Brazil: a review. Acta Bot Bras 17: 561-584.

Gunji S, Arima K, Beppu T 1983. Screening of antifungal antibiotics according to activities inducing morphological abnormalities. Agric Biol Chem 47: 2061-2069.

Kartsonis N, Nielsen J, Douglas C 2003. Caspofungin: the first in a new class of antifungal agents. Drug Resist Update 6: 197-218.

Lee SH, Lee JR, Lunde CS, Kubo I 1999. In vitro antifungal susceptibilities of Candida albicans and other fungal pathogens to polygodial, a sesquiterpene dialdehyde. Planta Med 65: 204-208.

Lima MR, de Souza Luna J, dos Santos AF, de Andrade MC, Sant'Ana AE. Genet JP, Marquez B, Neuville L, Moreau N. 2006. Anti-bacterial activity of some Brazilian medicinal plants. J Ethnopharmacol 21: 137-147.

Matos FJA 1988. Introdução à fitoquímica experimental. Imprensa Universitária da Universidade Federal do Ceará, Fortaleza

Mota Menezes V, Atallah AN, Lapa AJ, Catapani WR 2006. Assessing the therapeutic use of Lafoensia pacari St. Hil. extract (mangava-brava) in the eradication of Helicobacter pylori: double-blind randomized clinical trial. Helicobacter 11: 188-195.

Müller V, Chávez JH, Reginatto FH, Zucolotto SM, Niero R, Navarro D, Yunes RA, Schenkel EP, Barardi CR, Zanetti CR, Simões CM 2007. Evaluation of antiviral activity of South American plant extracts against herpes simplex virus type 1 and rabies virus. Phytother Res 21: 970974.

Murakami S, Isobe Y, Kijima H, Nagai H, Muramatu M, Otomo $\mathrm{S}$ 1991. Inhibition of gastric $\mathrm{H}+, \mathrm{K}(+)$-ATPase and acid secretion by ellagic acid. Planta Med 57: 305-308.

Onishi J, Meinz M, Curotto J, Dreikorn S, Rosenbach M, Douglas C, Abruzzo G, Flattery A, Kong L, Cabello A, Vicente F, Pelaez F, Diez M, Martin I, Bills G, Giacobbe R, Dombrowski A, Schwartz R, Morris S, Harris G, Tsipouras A, Wilson K, Kurtz M 2000. Discovery of novel antifungal $(1,3) \beta$-D-glucan synthase inhibitors. Antimicrob Agents Chemother 44: 368-377.

Quindos G 2002. Las micosis en el amanecer del siglo XXI. Rev Iberoam Micol 19: 1-4.

Rogerio AP, Sa-Nunes A, Albuquerque DA, Anibal FF, Medeiros
AI, Machado ER, Souza AO, Prado JCJ, Faccioli LH 2003. Lafoensia pacari extract inhibits IL-5 production in toxocariasis. Parasite Immunol 25: 393-400.

Rogerio AP, Fontanari C, Borducchi E, Keller AC, Russo M, Soares EG, Albuquerque DA, Faccioli LH 2008a. Antiinflammatory effects of Lafoensia pacari and ellagic acid in a murine model of asthma. Eur J Pharmacol 580: 262270.

Rogerio AP, Fontanari C, Melo MC, Ambrosio SR, de Souza GE, Pereira OS, França SC, da Costa FB, Albuquerque DA, Faccioli LH 2006. Anti-inflammatory, analgesic and anti-oedematous effects of Lafoensia pacari extract and ellagic acid. J Pharm Pharmacol 58: 1265-73.

Rogerio AP, Sá-Nunes A, Albuquerque DA, Soares EG, Faccioli LH 2008b. Anti-eosinophilic effect of Lafoensia pacari in toxocariasis. Phytomedicine 15: 348-57.

Solon S, Lopes L, Teixeira de Souza PJ, Schmeda-Hirschmann G 2000. Free radical scavenging activity of Lafoensia pacari. J Ethnopharmacol 72: 173-178.

Solon S 1999. Alguns aspectos Químico-Farmacológicos da Entrecasca do Caule da Lafoensia pacari St. Hil. (Mangava-brava, Lythraceae). Cuiabá, 110 p. Dissertação de Mestrado, Programa de Pós-graduação em Saúde e Ambiente, Universidade Federal de Mato Grosso.

Tamashiro-Filho P 1999. Avaliação da atividade antiúlcera do extrato bruto metanólico de Lafoensia pacari St. Hil. (mangava-brava). Cuiabá, 129 p. Dissertação de Mestrado, Programa de Pós-graduação em Saúde e Ambiente, Universidade Federal de Mato Grosso.

Zacchino S, Yunes R, Cechinel V, Enriz RD, Kouznetsov V, Ribas JC 2003. The need for new antifungal drugs: Screening for antifungal compounds with a selective mode faction with emphasis on the inhibitors of the fungal cell wall. In: Mahendra Rai, Donatella Mares (Eds.) Plant Derived Antimycotics, Haworth Press (New York); 1-47. 